\title{
MAPPING FLOOD HAZARDS BY MULTI-CRITERIA DECISION ANALYSIS TECHNIQUE IN GEOGRAPHIC INFORMATION SYSTEM (GIS-MCDA)
}

\author{
M.Abo-Taha ${ }^{1}, *$, Hany Ahmed ${ }^{2}$, Anas El-Molla ${ }^{2}$
}

${ }^{1}$ Civil Engineering Department, Faculty of Engineering, Ahram Canadian University, Giza, Egypt.

${ }^{2}$ Civil Engineering Department. Dept., Faculty of Engineering, Al-Azhar University, Cairo, Egypt. *Corresponding Author E-mail: mohamedlotfi11084@yahoo.com

Received :12 Sept. $2021 \quad$ Accepted:26 Oct. 2021

\begin{abstract}
In terms of the importance of constructing new mega-urban zones to achieve future sustainable urban development for Egypt's Vision 2030, this research was initiated with the objective of protecting such zones by mapping flood hazards by "Multi-Criteria Decision Analysis" based on "Geographic Information System" (GIS-MCDA), where the Hegaza Village - Qena Governorate in Upper Egypt was taken as a study area. Accordingly, a research methodology was planned to encompass five investigations (Theoretical, field, numerical, analytical and inferential investigations). The hydrology of the study area was modeled by blending GIS Model-Builder and the hydrological model (HEC-1). A flood hazard map (F.H.M) was produced based on (GIS-MCDA), in terms of the Analytic Hierarchy Process (AHP). The research flagged out that the obtained results would most probably assist decisionmakers. In addition, the research highlighted the importance of implementing flood hazards management activities to ensure the environmental rehabilitation of watersheds to avoid flood disasters.
\end{abstract}

KEYWORDS: GIS, Model Builder, MCDA, AHP, F.H.M

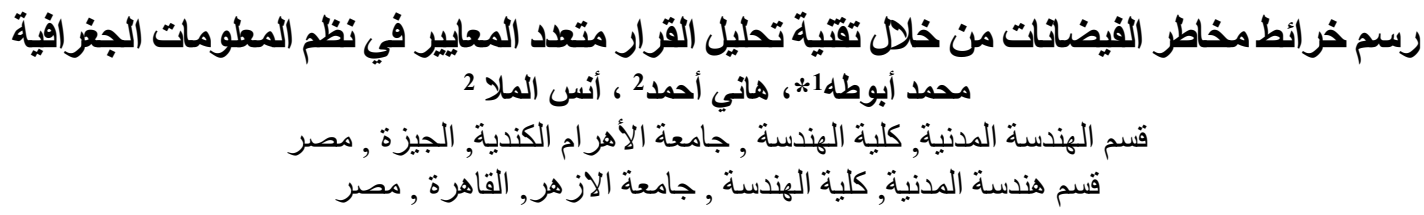

من حيث أهمية إنشاء مناطق حضرية عملاقة جديدة لتحقيق التنمية الحضرية المستدامة المستقبلية لرؤية مصر 2030 ، بدأ هذا البحث بهدف حماية هذه المناطق من خلال رسم خر ائط لمخاطر الفيضانات بإستخدام تقنية تحليل القرار منعدد المعايير القائمة على نظم المعلومات الجغر افية GIS-MCDA، حيث اتخذت قرية حجازة في صعيد مصر كمنطقة در اسة. وفقًا لذللك ، تم التخطبط لمنهجية البحث

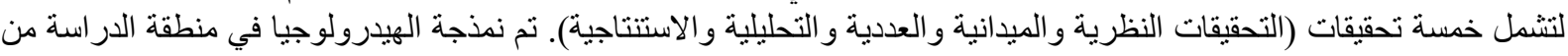

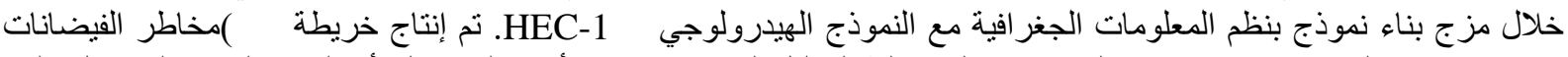

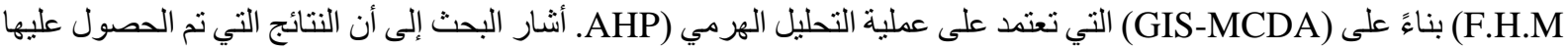
ستساعد على الأرجح صانعي القرار في الدولة لاتخاذ التدابير اللازمة لضمان إعادة التأهيل البيئي لمستجمعات المياه لتجنب كوارث

الكلمات المفتاحية : نظم المعلومات الجغرافية, باني النموذج, تحليل القرار متعدد المعايير, عملية التحليل الهرمي, خريطة مخاطر 
MAPPING FLOOD HAZARDS BY MULTI-CRITERIA DECISION ANALYSIS TECHNIQUE IN GEOGRAPHIC INFORMATION SYSTEM (GIS-MCDA)

\section{INTRODUCTION}

Flood hazard impacts are worldwide documented. However, their management is significantly important to avoid such impacts. In addition, many flood disasters were historically documented, where 2.3 billion were affected during 1995-2017. Moreover, financial losses reached 662 billion dollars (Wahlstrom and Guha-Sapir, 2015) [1]. Accordingly, flood hazards should be reduced (Billa, et al, 2006) [2]and floodrisk maps should be produced (Bubeck, et al, 2012) [3]. Accordingly, this research was initiated with the objective of protecting urban zones by mapping their exposure to flood hazard. During the theoretical investigation, literature in the field of GIS so as MCDA was assembled and scrutinized, from which it was clear that many researchers are involved in the field of flood hazards. Among these researchers was (Yang, et al, 2018) [4], who documented that hydrological so as hydraulic modeling programs emerged simultaneously with the emergence of GIS so as satellite-remote-sensing-imagery together with Digital Elevations Model (DEM). In addition, (EU IPA 2010 TWINNING PROJECT, 2010) [5] stated that mapping hazardous zones are essential for flood hazards management, flood-protection and land-useplanning. Moreover, The Committee on Floodplain Mapping Technologies (2007) [6] favored GIS in mapping flood risk due to its preeminence in analysis and manipulating enormous spatial data. However, Gericke and Plessis (2012) [7] compared watershed characteristics by ArcGIS to the manual calculations, where they assured that the obtained results of ArcGIS are superior as they consume, almost, no time. Furthermore, Kourgialas and Karatzas (2016) [8] assessed mapped flood risk in Crete using rainfall and topography data. Likewise, Al-Abadi et al. (2016) [9] implemented topographic data to evaluate flood risk in the south of Iraq watershed. Nevertheless, De Brito and Evers (2016) [10] implemented AHP in assessing flood risk, as it is a multiple criteria assessment method that captures all factors together with their inter-relationships. Similarly, (Kazakis, et al, (2015) [11]; Khosravi, et al (2016) [12]; Khaleghi and Mahmoodi, (2017) [13]; Rimba, et al, (2017) [14]; Patrikaki, et al (2018) [15]; Ahmed H. (2021) [16]) implemented MCDA, as it calculates the weight of each criterion by AHP. However, (Ghabayen and Salha (2013) [17]; Omran et al. (2011) [18]; Magesh and Ch, N. (2012) [19]; Elmoustafa et al. (2015) [20]) implemented ArcGIS as it is applicable to long data analysis steps, where Model-Builder could automate such processes. Based on scrutinizing the assembled literature, this technique was selected to be applied in this research to innovate a suitable economic protection measure.

\section{FIELD INVESTIGATION}

All through the field investigation, site visits were carried out to the study area (Hegaza Village in Qus Center in Qena Governorate in Upper Egypt), where field data were assembled and field observations were carried out. Based on the site visits and assembled data, it was clear that its area is 30 million $\mathrm{m}^{2}$ according to the administrative division of Egypt 2017. The village is surrounded by the eastern desert at the East, Kalalsa Village at the West, Al-Kalahin Village at the North and Khuzam Village at the South, figure (1). Based on 1: 50,000 topographic maps, it was obvious that Hegaza has 3 watersheds evolving from the Red Sea Mountains (Wadi Hegaza - Wadi Al Uqab - Wadi Al- Tameed). According to data obtained from the Information and Decision Support Center - Qena Governorate General Office, Hegaza is the 2nd Qena governorate village exposed to flood hazards during 1934-2017, where it was exposed 10 times to floods and its exposure to hazards (from surface runoff) is $22 \%$ of the number of exposures of Qena villages; table (1).

Table 1: The frequency of floods in the cities and villages of Qena Governorate from 1934 to 2017

\begin{tabular}{|c|c|c|c|c|c|c|c|c|}
\hline Location & $\begin{array}{c}\text { Nagaa } \\
\text { Hammadi } \\
\text { Center }\end{array}$ & $\begin{array}{c}\text { Deshna } \\
\text { center }\end{array}$ & $\begin{array}{l}\text { Qena } \\
\text { city }\end{array}$ & $\begin{array}{c}\text { Karam Amran } \\
\text { village }\end{array}$ & $\begin{array}{l}\text { Kalahin } \\
\text { Village, } \\
\text { Qift }\end{array}$ & $\begin{array}{l}\text { Hegaza } \\
\text { village }\end{array}$ & $\begin{array}{c}\text { The village of } \\
\text { Khazam in } \\
\text { Qous }\end{array}$ & Total \\
\hline $\begin{array}{c}\text { Number of } \\
\text { floods }\end{array}$ & 3 & 3 & 12 & 9 & 2 & 10 & 6 & 45 \\
\hline $\begin{array}{c}\text { Relative } \\
\text { importance \% }\end{array}$ & 6.7 & 6.7 & 26.7 & 20 & 4.4 & 22.2 & 13.3 & 100 \\
\hline
\end{tabular}


MAPPING FLOOD HAZARDS BY MULTI-CRITERIA DECISION ANALYSIS TECHNIQUE IN GEOGRAPHIC INFORMATION SYSTEM (GIS-MCDA)

\section{NUMERICAL INVESTIGATION}

In the numerical investigation, the maximum precipitation on the watersheds was determined. In addition, the streams and basins were demarcated using Model-Builder. Furthermore, a flood hazard map (F.H.M) was produced based on the multi-criteria decision analysis of the GIS (GIS-MCDA), in terms of the Analytic Hierarchy Process (AHP). This is presented, as follows:

\subsection{Maximum Precipitation}

During the numerical investigation, the maximum precipitation on the watersheds was determined in order to calculate the accumulated floods, where 36 years (1979-2014) of global data was obtained from globalweather.tamu.edu[21]. A Weibull method in (Hyfran) program was used in the statistical distribution as shown in figure (2) and the precipitation depth was determined for different return periods; table (2).

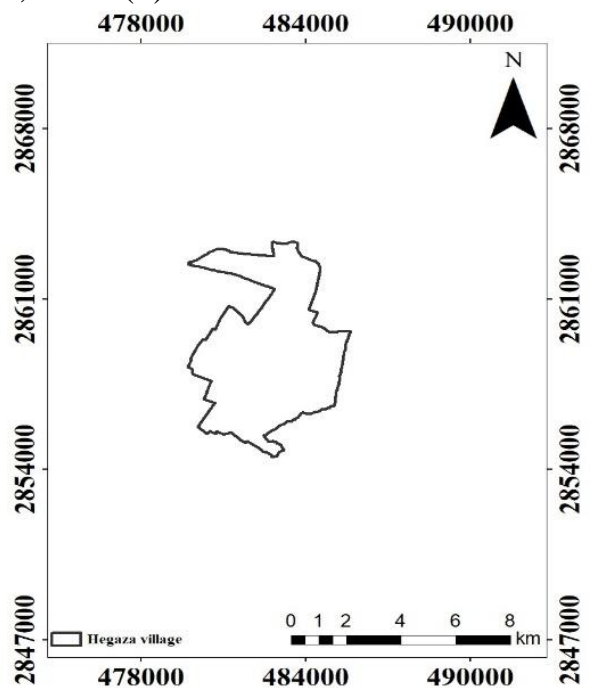

Fig. 1: Location of the study area (Hegaza Village)

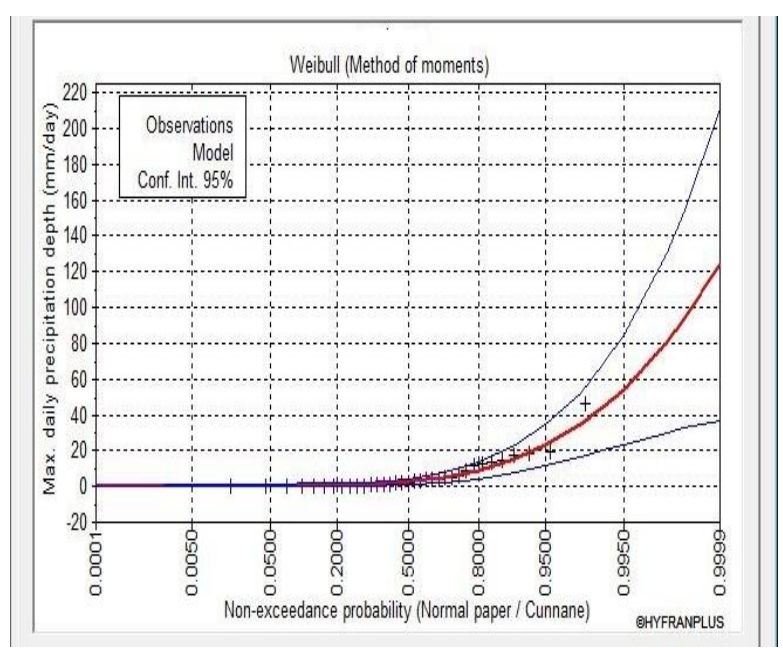

Fig. 2: Probability distribution curve for precipitation data using the Weibull method

Table 2: Precipitation depth by Weibull method for different return periods

\begin{tabular}{|c|c|c|c|c|c|c|c|}
\hline \multirow{2}{*}{ Longitude } & \multirow{2}{*}{ Latitude } & \multicolumn{5}{|c|}{ Max.24 hr. precipitation depth (mm/day) for different return periods } \\
\cline { 3 - 9 } & & 5 years & 10 years & 20 years & 25 years & 50 years & 100 years \\
\hline 32.5 & 25.134399 & 9.19 & 15.7 & 23.2 & 25.8 & 34.5 & 44.1 \\
\hline
\end{tabular}

\subsection{Drainage Streams}

Through the numerical investigation, the streams and basins were defined or demarcated using ModelBuilder of the GIS, where Model-Builder is an application that creates and manages models; figure (3). It strings the geo-processing tools and feeds the output as an input of one tool to another. Model-Builder constructs and executes simple workflows. It provides methods to extend the functionality of ArcGIS. Model-Builder integrates ArcGIS with other applications, where DEMs (Digital Elevation Models), with an accuracy of $30 \mathrm{~m}$, were implemented via earthexplorer.usgs.gov[22]. 


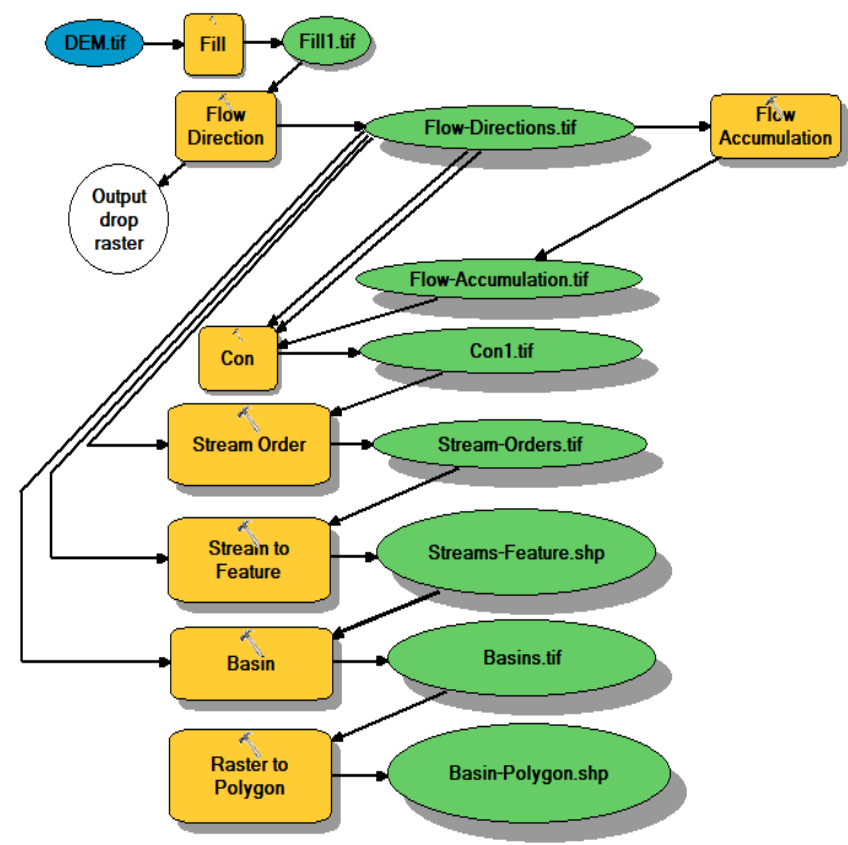

Fig. 3: Model-Builder in GIS

Internally, the implemented model goes through the following computational steps:

- It fills the sinks in a raster.

- It creates a flow raster from the cell to its neighbor.

- It creates an accumulated flow raster to the cell .

- It optionally performs an evaluation to the raster cells .

- It denotes segment order to represent linear network

- It creates a raster to delineate drainage basins.

The calibration of this model was done by entering the same study area and the same data used into the Watershed Modeling System program (WMS), showing that there is a clear match between them. From the simulation, it was apparent that the streams that affect Hegaza Village are classified into 5 classes, where 5, 4, 3, 2 and 1 indicate very high, high, medium, low and very low hazards, respectively. Table (3) lists the stream statistics of Hegaza Village. Figure (4) presents the watersheds that affect Hegaza Village.

Table 3: Stream statistics affecting Hegaza Village

\begin{tabular}{|c|c|c|}
\hline Stream order & Sum_Length $(\mathrm{Km})$ & percentage $\%$ \\
\hline Very low & 159.854152 & $48.607 \%$ \\
\hline Low & 92.948106 & $28.263 \%$ \\
\hline medium & 52.547389 & $15.978 \%$ \\
\hline High & 17.795443 & $5.411 \%$ \\
\hline Very high & 5.727424 & $1.742 \%$ \\
\hline
\end{tabular}

\subsection{Morphological Identities}

During the numerical investigation, the morphological characteristics were extracted by integrating drainage streams and drainage basins. The morphological characteristics of the main basins are shown in table (4). 
Table4: The morphological characteristics of main basins

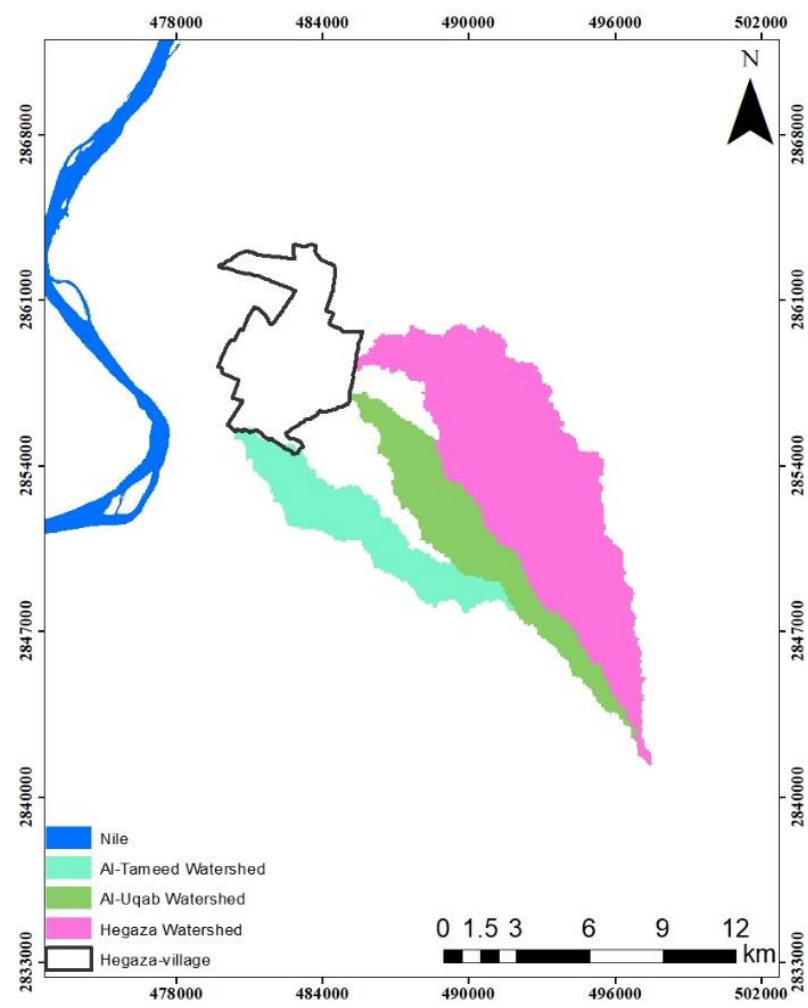

\begin{tabular}{|c|c|c|c|}
\hline & $\begin{array}{c}\text { Wadi } \\
\text { Hegaza }\end{array}$ & $\begin{array}{l}\text { Wadi Al- } \\
\text { Uqab }\end{array}$ & $\begin{array}{c}\text { Wadi Al- } \\
\text { Tameed }\end{array}$ \\
\hline Area $\left(\mathrm{km}^{2}\right)$ & 70.44 & 26.05 & 21.77 \\
\hline $\begin{array}{c}\text { Basin } \\
\text { Slope }(\mathrm{m} / \mathrm{m})\end{array}$ & 0.0458 & 0.0503 & 0.0500 \\
\hline $\begin{array}{c}\text { Basin } \\
\text { Length }(\mathrm{m})\end{array}$ & 21015.9 & 18715.82 & 13742.17 \\
\hline $\begin{array}{c}\text { Perimeter } \\
(\mathrm{m})\end{array}$ & 74822.04 & 57645.52 & 44836.29 \\
\hline $\begin{array}{c}\text { Shape Factor } \\
\left(\mathrm{mi}^{2} / \mathrm{mi}^{2}\right)\end{array}$ & 6.27 & 13.45 & 8.67 \\
\hline $\begin{array}{c}\text { Mean Basin } \\
\text { Elevation }(\mathrm{m})\end{array}$ & 190.47 & 194.6 & 147.24 \\
\hline $\begin{array}{c}\text { Max. Flow } \\
\text { Distance (m) }\end{array}$ & 29414.27 & 22814.54 & 18738.27 \\
\hline $\begin{array}{c}\text { Max. Flow } \\
\text { Slope }(\mathrm{m} / \mathrm{m})\end{array}$ & 0.0082 & 0.0098 & 0.0092 \\
\hline $\begin{array}{l}\text { Max. Stream } \\
\text { Length }(\mathrm{m})\end{array}$ & 28831.21 & 22097.10 & 18030.89 \\
\hline $\begin{array}{l}\text { Max. Stream } \\
\text { Slope }(\mathrm{m} / \mathrm{m})\end{array}$ & 0.0081 & .0096 & 0.0085 \\
\hline
\end{tabular}

Fig. 4: Watersheds affecting Hegaza Village

\subsection{Watersheds Curve Number}

Via the numerical investigation, the effective precipitation amounts were calculated, where the rainfall losses represented by relating the total rainfall to the surface runoff by implementing the curve number method. This method depends on the combination of 2 important elements in the study area (definition of hydrological groups and the land use).

\subsubsection{Soil Hydrological Group}

During the numerical investigation, the Soil Conservation Services (SCS) 1985[23] technique was implemented, where the soil was classified into 4 groups (A, B, C and D). They ranged between 0 and 100, where the Digital Soil Map of the World was obtained via fao.org/geonetwork/srv/en/metadata[24]. The hydrological groups (B and C) are presented in figure 5.

\subsubsection{Soil Land Use}

The soil land use was defined by incorporating satellite visuals via Landsat 8 / OLI[25], where the analysis classified it into 3 categories (desert, agricultural and urban areas); figure (6).

\subsubsection{Watershed Curve Number}

Implementing the GIS, the hydrological group was combined with the land use and the Watersheds affecting the Hegaza Village, curve numbers were defined to be 83.57 for Hegaza watershed, 84.132for Al-Uqap watershed and 82.4 for Al-Tameed watershed

\section{5 .Watersheds Precipitation Depth}

Via the numerical investigation, the precipitation depth of the watersheds in Hegaza Village was determined, for a return period of 100 years. This was achieved by interpolating a raster surface from points using IDW “Inverse Distance Weighted” technique; figure (7). 
MAPPING FLOOD HAZARDS BY MULTI-CRITERIA DECISION ANALYSIS TECHNIQUE IN GEOGRAPHIC INFORMATION SYSTEM (GIS-MCDA)

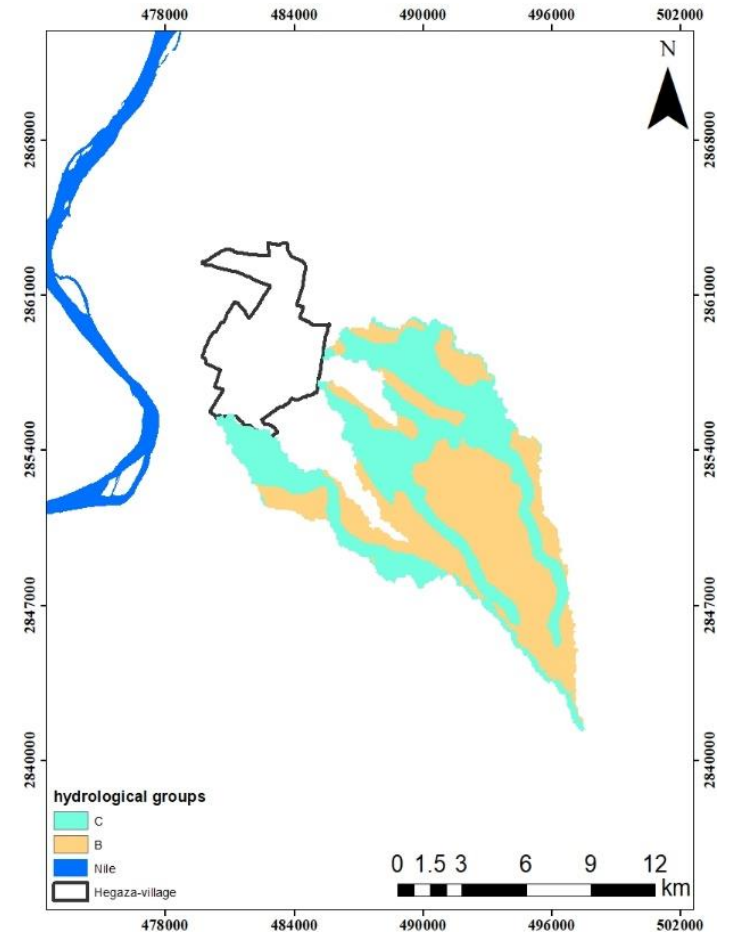

Fig. 5: Hydrological groups of Watersheds in Hegaza Village

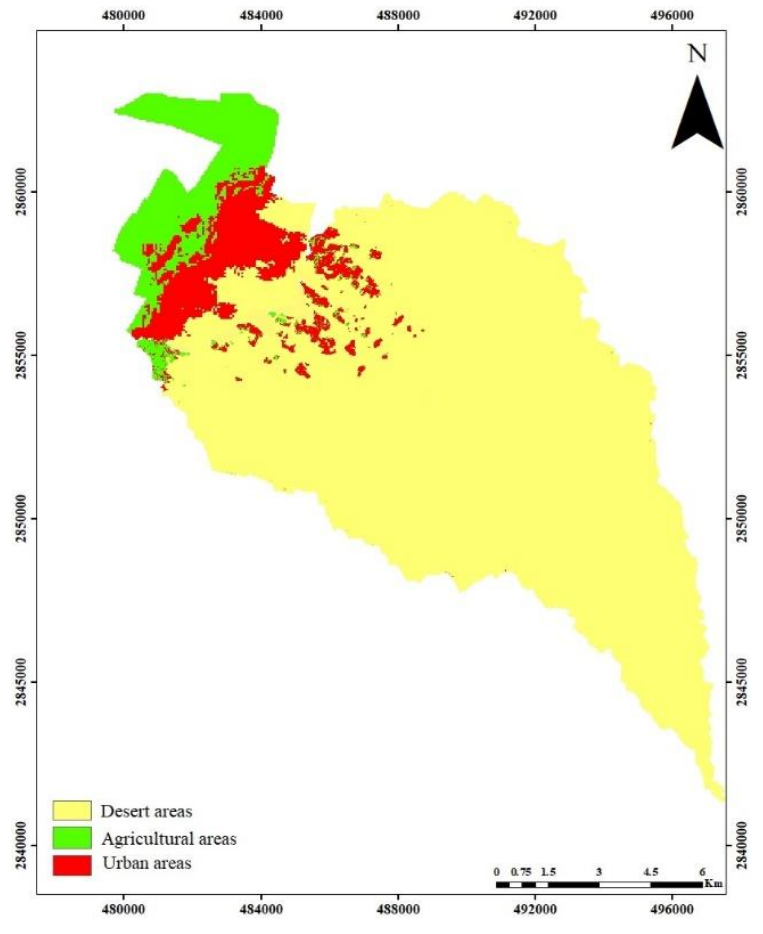

Fig. 6: Land use map in Hegaza village

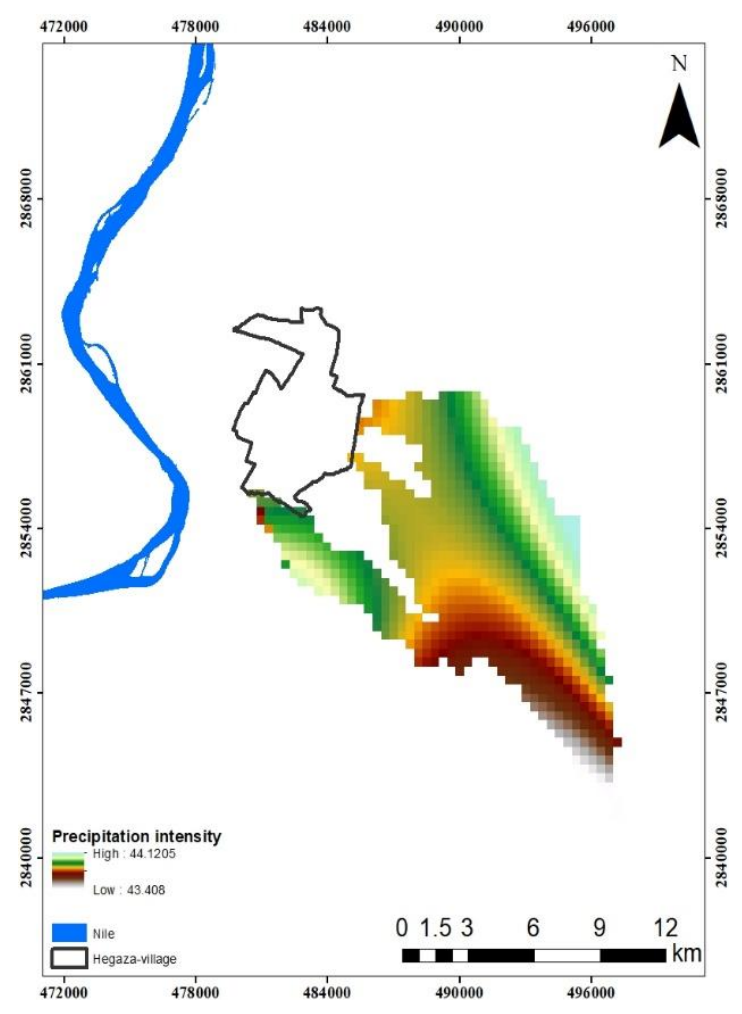

Fig. 7: Precipitation depth for a return period 100 years in Hegaza Village 


\subsection{GIS-MCDA}

During the numerical investigation, the multi-criteria decision analysis based on GIS was implemented for the 7 significant criteria affecting flood hazards frequency. The weight of each criterion was determined by AHP. These criteria encompassed:

- Flow accumulation

- Euclidean distance

- Slope

- Precipitation intensity

- Drainage Density

- Land use

- Hydrological groups

The seven extracted criteria layers were reclassified in ArcGIS, to determine the degree of severity and to create the hazard maps. The reclassify tool (in the spatial analysis toolbox in ArcGIS) was applied to determine and define the hazard classes and ranks for each criterion. Hazard classes and ranks were assigned for each criterion using the experience of the authors and extensive previous studies. Classification categories of the seven main criteria affecting flooding in the study area as shown in table (5).

Table 5: Classification categories of the seven main criteria

\begin{tabular}{|c|c|c|}
\hline criterion & Categories & $\begin{array}{c}\text { Category } \\
\text { value }\end{array}$ \\
\hline \multirow{5}{*}{ Flow accumulation } & $0-16565.6$ & 2 \\
\hline & $16565.6-33131.2$ & 4 \\
\hline & $33131.2-49696.8$ & 6 \\
\hline & $49696.8-66262.4$ & 8 \\
\hline & $66262.4-82828$ & 10 \\
\hline \multirow{5}{*}{ Euclidean distance } & $0-99.7806$ & 10 \\
\hline & $99.7806-199.5612$ & 8 \\
\hline & $199.5612-299.3418$ & 6 \\
\hline & $299.3418-399.1224$ & 4 \\
\hline & $399.1224-498.903$ & 2 \\
\hline \multirow{5}{*}{ Slope } & $0-4.7$ & 2 \\
\hline & $4.7-9.4$ & 4 \\
\hline & $9.4-14.1$ & 6 \\
\hline & $14.1-18.8$ & 8 \\
\hline & $18.8-23.5$ & 10 \\
\hline \multirow{5}{*}{ Precipitation intensity } & $43.408-43.5505$ & 2 \\
\hline & $43.5505-43.693$ & 4 \\
\hline & $43.693-43.8355$ & 6 \\
\hline & $43.8355-43.978$ & 8 \\
\hline & $43.978-44.1205$ & 10 \\
\hline \multirow{5}{*}{ Drainage Density } & $1-1.8$ & 2 \\
\hline & $1.8-2.6$ & 4 \\
\hline & $2.6-3.4$ & 6 \\
\hline & $3.4-4.2$ & 8 \\
\hline & $4.2-5$ & 10 \\
\hline \multirow{3}{*}{ Land use } & Agricultural areas & 4 \\
\hline & Urban areas & 6 \\
\hline & Desert areas & 8 \\
\hline \multirow{2}{*}{ Hydrological groups } & Group B & 6 \\
\hline & Group C & 8 \\
\hline
\end{tabular}

Similarly, the weight of each criterion is ranked based on the AHP method; table (6), where their total is $100 \%$. The 7 criteria were combined, in terms of the weight in GIS-Model-Builder figure (8). 
MAPPING FLOOD HAZARDS BY MULTI-CRITERIA DECISION ANALYSIS TECHNIQUE IN GEOGRAPHIC INFORMATION SYSTEM (GIS-MCDA)

Table 6: Weights of the eight criteria of the study using the AHP.

\begin{tabular}{|c|c|c|c|}
\hline Criteria & Total of Rows & Relative Weight & Weight \% \\
\hline Flow accumulation & 2.45 & 0.35 & $35.04 \%$ \\
\hline Euclidean distance & 1.66 & 0.24 & $23.75 \%$ \\
\hline Slope & 1.11 & 0.16 & $15.90 \%$ \\
\hline Precipitation intensity & 0.74 & 0.11 & $10.56 \%$ \\
\hline Drainage Density & 0.49 & 0.07 & $6.96 \%$ \\
\hline Land use & 0.32 & 0.05 & $4.62 \%$ \\
\hline Hydrological groups & 0.22 & 0.03 & $3.18 \%$ \\
\hline Total & 7 & 1.00 & $100.00 \%$ \\
\hline
\end{tabular}

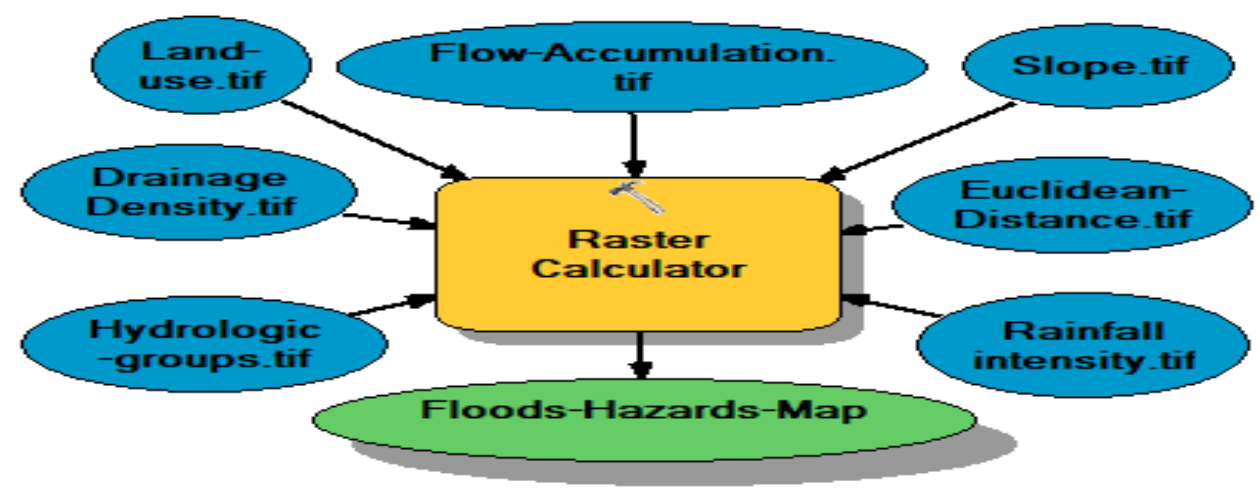

Fig. 7: GIS-Model-Builder (GIS-MCDA)

The calibration of this model was done by comparing the flood hazard map produced through this model with the flood hazard map produced by hydrodynamic modeling by (Abo-Taha M., et al, (2021) [26]), showing that there is a clear match between them.

\section{RESULTS AND DISCUSSION}

In the analytical investigation, the obtained results were analyzed, presented and discussed, from which the following were designated

- From the GIS-model Builder, three main watersheds affect the village of Hegaza, which are in order from North to South: Wadi Hegaza, Wadi Al-Uqab, Wadi Tameed. Total lengths of streams within the watersheds affecting the village of Hegaza $328.87 \mathrm{~km}$.

- The discharge and volume of the runoff at the outlet of watersheds affecting the village of Hegaza were determined by the hydrological model (HEC-1). The hydrographs at the outlet of the watersheds, for different return periods as shown in figures from 8 to 10 .

- The MCDA results based on GIS identified the hazardous degree of floods within the watersheds of Hegaza Village, where it was classified into 5 classes (very high, high, medium, low and very low hazards). it was found that the areas exposed to very high and high flood hazards amounted to $21.12 \mathrm{~km}^{2}$ and $28.35 \mathrm{~km}^{2}$, respectively, out of the total area of the three basins affecting the village of Hegaza estimated at $118.26 \mathrm{~km}^{2}$. The area of areas exposed to moderate flood hazards is $36.98 \mathrm{~km}^{2}$. Finally, the areas prone to low and very low flood hazards are $22.54 \mathrm{~km}^{2}$ and 9.27 $\mathrm{km}^{2}$, respectively; figure (11). 
MAPPING FLOOD HAZARDS BY MULTI-CRITERIA DECISION ANALYSIS TECHNIQUE IN GEOGRAPHIC INFORMATION SYSTEM (GIS-MCDA)

[1] Hydrograph

Flow vs. Time

PEAK: $27.14 \mathrm{cms}$ TIME OF PEAK: $1065 \mathrm{~min}$ VOLUME: $975292.20 \mathrm{~m} ` 3$

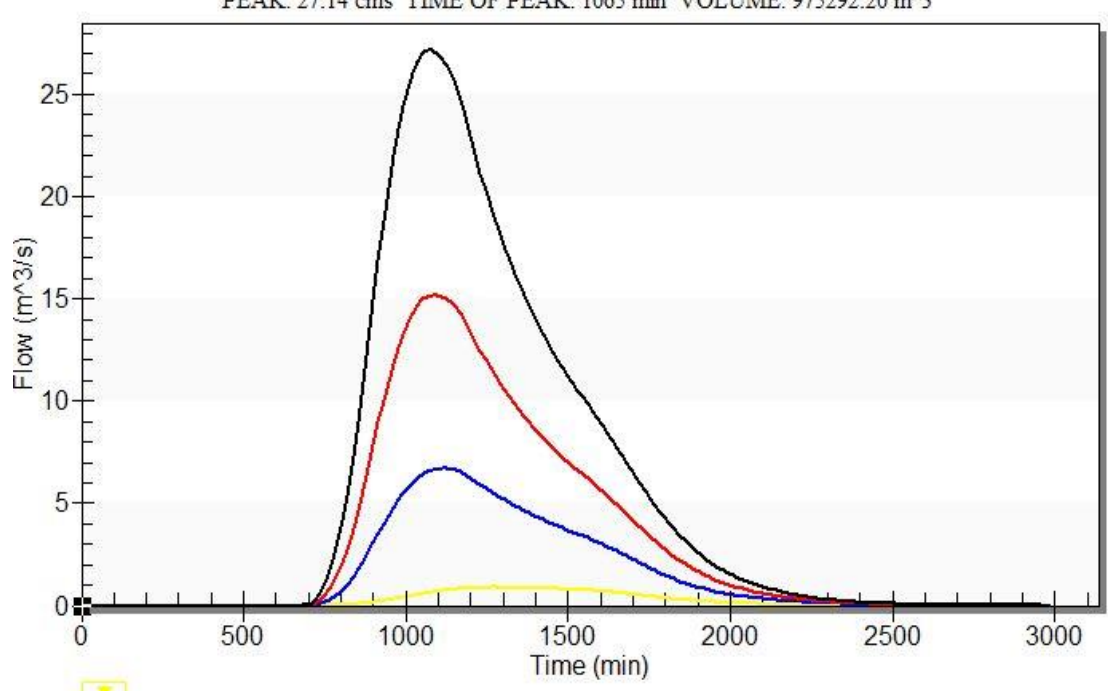

$\mathrm{T}=10$ (years).sol, 1B Ratio 1, P:0.89, T:1260, V:41302.8

$\checkmark$

$\mathrm{T}=25$ (years).sol, 1B Ratio 1, P:6.70, T:1110, V:267881.4

$\mathrm{T}=50$ (years).sol, $1 \mathrm{~B}$ Ratio 1, P:15.19, T:1080, V:568531.8

$\mathbf{7}$

$\mathrm{T}=100$ (years).sol, 1B Ratio 1, P:27.14, T:1065, V:975292.2

Fig. 8.: Wadi Hegaza Watershed flood flow hydrographs

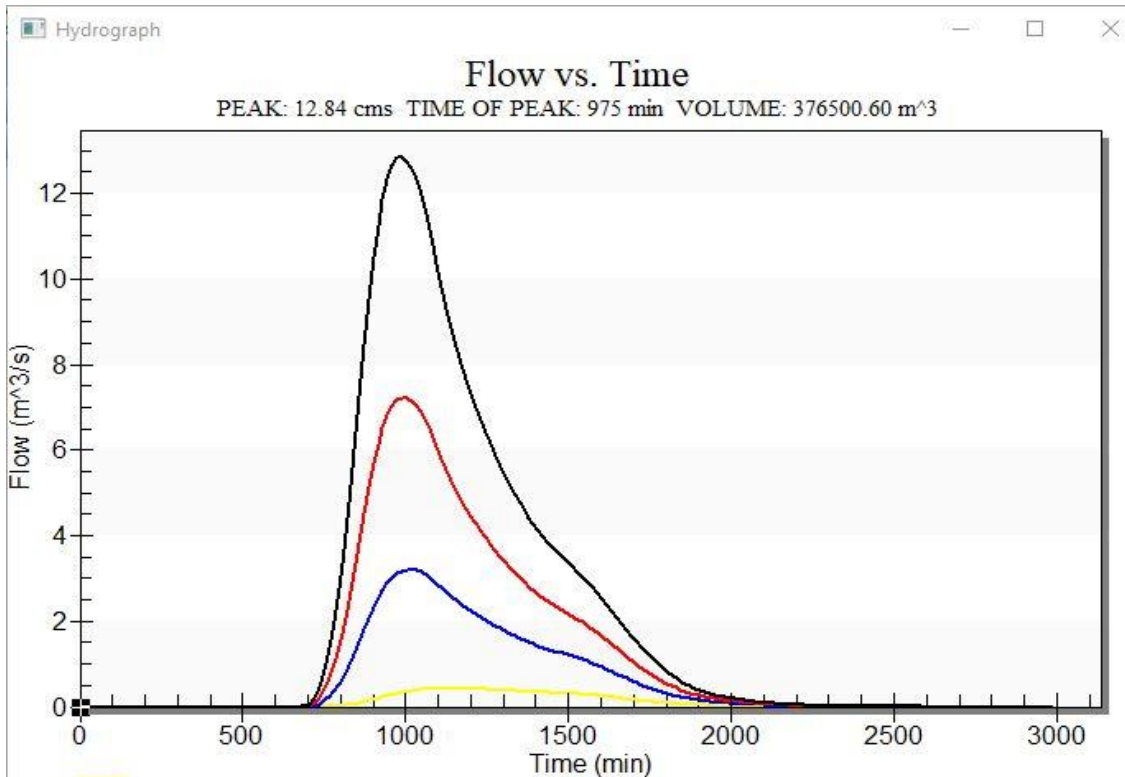

$\mathrm{T}=10$ (years).sol, 2B Ratio 1, P:0.43, T:1110, V:18044.1

7

$\mathrm{T}=25$ (years).sol, 2B Ratio 1, P:3.20, T:1020, V:106820.1

$\mathrm{T}=50$ (years).sol, 2B Ratio 1, P:7.22, T:990, V:222059.7

7

$\mathrm{T}=100$ (years).sol, 2B Ratio 1, P:12.84, T:975, V:376500.6

Fig. 9: Wadi Al-Uqap Watershed flood flow hydrographs 
MAPPING FLOOD HAZARDS BY MULTI-CRITERIA DECISION ANALYSIS TECHNIQUE IN GEOGRAPHIC INFORMATION SYSTEM (GIS-MCDA)

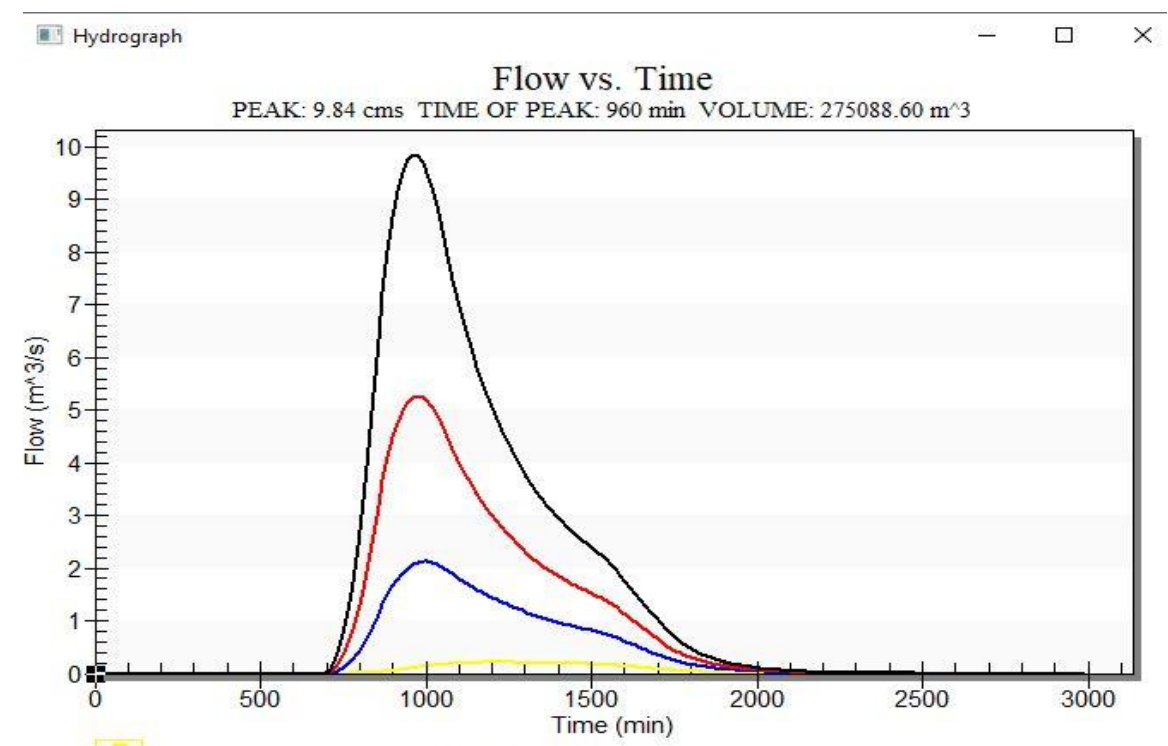

$T=10$ (years).sol, 3B Ratio 1, P:0.20, T:1185, V:8661.6
$\square=25$ (years).sol, 3B Ratio 1, P:2.13, T:1005, V:70319.7
$T=50$ (years).sol, 3B Ratio 1, P:5.26, T:975, V:156321.9
$T=100$ (years).sol, 3B Ratio 1, P:9.84, T:960, V:275088.6

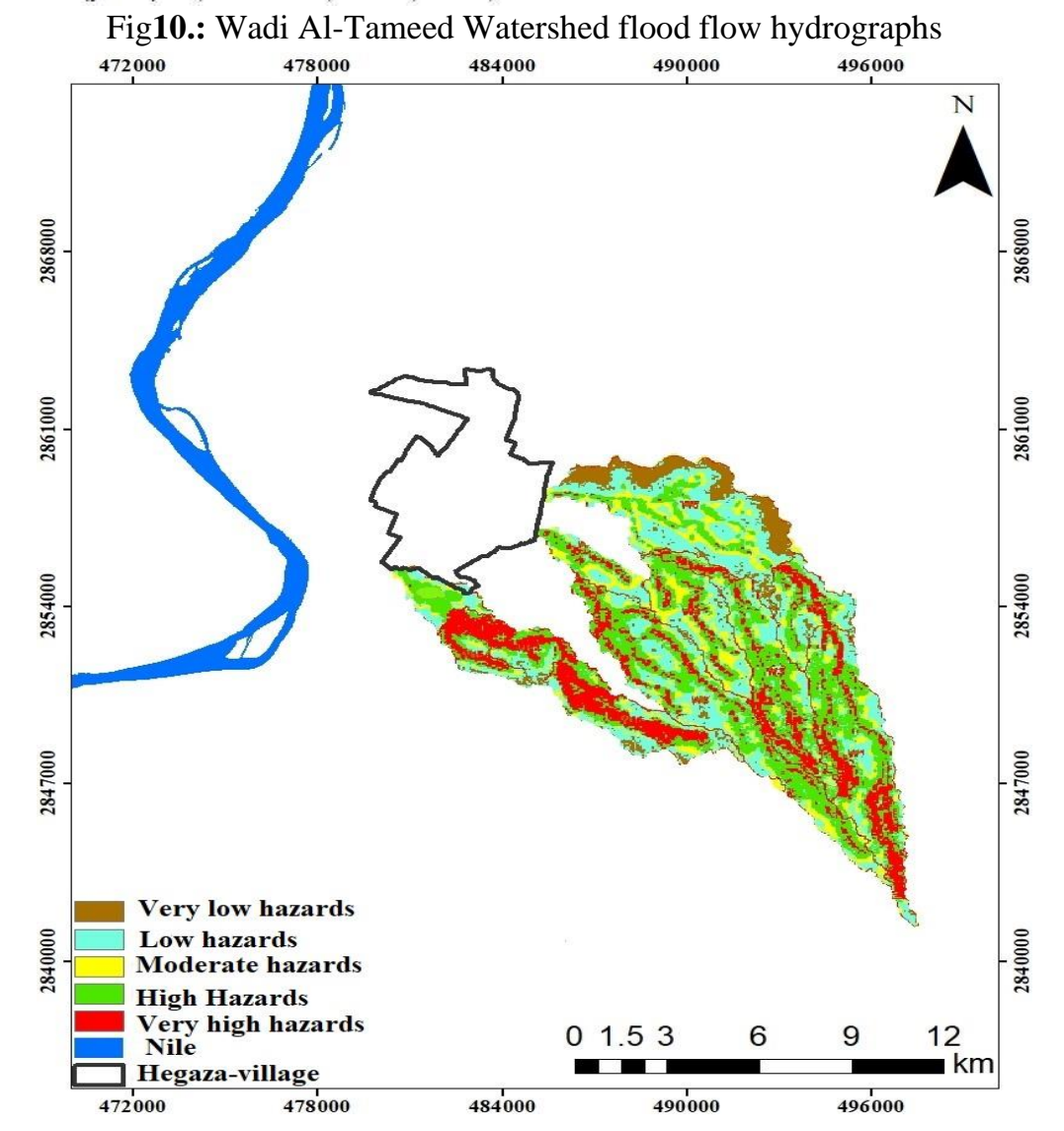

Fig. 11: Floods hazards map 
MAPPING FLOOD HAZARDS BY MULTI-CRITERIA DECISION ANALYSIS TECHNIQUE IN GEOGRAPHIC INFORMATION SYSTEM (GIS-MCDA)

\section{CONCLUSION}

During the inferential investigation, conclusions were deduced, as follows :

- The research flagged out that the obtained results would most probably assist decision-makers .

- The research highlighted the importance of implementing flood hazards management activities to ensure the environmental rehabilitation of watersheds to avoid flood disasters.

- The research emphasized that the GIS-MCDA is a new approach to local flood hazard assessment mapping and it empowers decision-makers in undertaking flood hazard management activities .

- The research results highlighted that GIS- MCDA could assist decision-makers to innovate a suitable economic protection measure.

- The hydrological modeling results indicated that it GIS is capable of extracting drainage streams, drainage basins and morphological characteristics .

- Model-Builder results identified 3 main watersheds. These are Wadi Hegaza, Wadi Al Aqab and Wadi Al Tamid with areas of $70.44,26.05 \mathrm{Km}^{2}$ and $21.77 \mathrm{Km}^{2}$, respectively. Their stream length is $328.87 \mathrm{~km}$.

- The modeling results identified the maximum discharge at 3 outlets for return periods of 10,25 , 50, and 100 years. The peak of the discharge of the three main basins affecting the village of Hegaza was based on the use of the value of the maximum precipitation depth for a return period of 100 years, resulting from the statistical analysis of rainfall using the (Hyfran) program 27.14 $\mathrm{m}^{3} / \mathrm{sec}, 12.84 \mathrm{~m}^{3} / \mathrm{sec}$ and $9.84 \mathrm{~m}^{3} / \mathrm{sec}$ respectively .

- The research results demarcated the very high and high hazard areas amounted to $21.12 \mathrm{~km}^{2}$ and $28.35 \mathrm{~km}^{2}$, respectively.

During the inferential investigation, recommendations were suggested, as follows:

-It is recommended to implement the utilized approach, as it assists in flood hazards management activities .

-It is suggested to utilize the implemented approach, as it ensures environmental rehabilitation of watersheds.

-It endorsed the application of the employed approach, as it ensures the reduction of flood disasters.

\section{REFERENCES}

1. Wahlstrom, M., \& Guha-Sapir, D. (2015). The human cost of weather-related disasters 1995-2015. Geneva, Switzerland: UNISDR.

2. Billa, L., Shattri, M., Mahmud, A. R., \& Ghazali, A. H. (2006). Comprehensive planning and the role of SDSS in flood disaster management in Malaysia. Disaster Prevention and Management: An International Journal.

3. Bubeck, P., Botzen, W. J. W., \& Aerts, J. C. (2012). A review of risk perceptions and other factors that influence flood mitigation behavior. Risk Analysis: An International Journal, 32(9), 1481-1495.

4. Yang, S. Y., Chan, M. H., Chang, C. H., \& Chang, L. F. (2018). The damage assessment of flood risk transfer effect on surrounding areas arising from the land development in Tainan, Taiwan. Water, 10(4), 473.

5. EU IPA 2010 TWINNING PROJECT, (2010), "the preparation of the Flood Risk Management Plans".

6. Committee on Floodplain Mapping Technologies, (2007). Elevation Data for Floodplain Mapping. National Academies Press. 
7. Gericke, O. J., \& Du Plessis, J. A. (2012). Catchment parameter analysis in flood hydrology using GIS applications. Journal of the South African Institution of Civil Engineering= Joernaal van die Suid-Afrikaanse Instituut van Siviele Ingenieurswese, 54(2), 15-26

8. Kourgialas, N. N., \& Karatzas, G. P. (2016). A flood risk decision making approach for Mediterranean tree crops using GIS; climate change effects and flood-tolerant species. Environmental Science \& Policy, 63, 132-142.

9. Al-Abadi, A. M., Shahid, S., \& Al-Ali, A. K. (2016). A GIS-based integration of catastrophe theory and analytical hierarchy process for mapping flood susceptibility: a case study of Teeb area, Southern Iraq. Environmental Earth Sciences, 75(8), 1-19

10. De Brito, M. M., \& Evers, M. (2016). Multi-criteria decision-making for flood risk management: a survey of the current state of the art. Natural Hazards and Earth System Sciences, 16(4), 1019-1033.

11. Kazakis, N., Kougias, I., \& Patsialis, T. (2015). Assessment of flood hazard areas at a regional scale using an index-based approach and Analytical Hierarchy Process: Application in Rhodope-Evros region, Greece. Science of the Total Environment, 538, 555563

12. Khosravi, K., Nohani, E., Maroufinia, E., \& Pourghasemi, H. R. (2016). A GIS-based flood susceptibility assessment and its mapping in Iran: a comparison between frequency ratio and weights-of-evidence bivariate statistical models with multi-criteria decision-making technique. Natural hazards, 83(2), 947-987.

13. Khaleghi, S., \& Mahmoodi, M. (2017). Assessment of flood hazard zonation in a mountainous area based on GIS and analytical hierarchy process. Carpathian J Earth Environ Sci, 12(1), 311-322.

14. Rimba, A. B., Setiawati, M. D., Sambah, A. B., \& Miura, F. (2017). Physical flood vulnerability mapping applying geospatial techniques in Okazaki City, Aichi Prefecture, Japan. Urban Science, 1(1), 7.

15. Patrikaki, O., Kazakis, N., Kougias, I., Patsialis, T., Theodossiou, N., \& Voudouris, K. (2018). Assessing flood hazard at river basin scale with an index-based approach: The case of Mouriki, Greece. Geosciences, 8(2), 50.

16. Ahmed H. (2021). (Floods Hazards Assessment by Integrating Hydrologic Modeling and a Geographic Information Systems (Multi-Criteria Decision Technique)). Journal of Al Azhar University, Engineering Sector, Cairo Egypt., October - AUEJ 2021.

17. Ghabayen, S. M., \& Salha, A. A. (2013). Crop water requirements (CWR) estimation in Gaza Strip using ArcMap-GIS model builder. Int J Emerg Tech Adv Eng, 3(10), 291-299

18. Omran, A., Schroder, D., El Rayes, A., \& Geriesh, M. (2011). Flood hazard assessment in Wadi Dahab, Egypt based on basin morphometry using GIS techniques. GI_Forum Program Committee.

19. Magesh, N. S., \& Ch, N. (2012). A GIS based automated extraction tool for the analysis of basin morphometry. Bonfring International Journal of Industrial Engineering and Management Science, 2(Special Issue Special Issue on Geospatial Technology Development in Natural Resource and Disaster Management), 32-35.

20. Elmoustafa, A. M., Farres, H. N., \& ElFawy, M. M. (2015). Effect of Elevation Data Accuracy on Storm Drainage Schemes, Lagos, Nigeria. Natural Resources, 6(07), 433

21. https://globalweather.tamu.edu/ 
MAPPING FLOOD HAZARDS BY MULTI-CRITERIA DECISION ANALYSIS TECHNIQUE IN GEOGRAPHIC INFORMATION SYSTEM (GIS-MCDA)

22. https://earthexplorer.usgs.gov/

23. SCS, U. (1985). National engineering handbook, section 4: hydrology. US Soil Conservation Service, USDA, Washington, DC.

24. https://data.apps.fao.org/map/catalog/srv/eng/catalog.search\#/home

25. https://www.usgs.gov/core-science-systems/nli/landsat/landsat-8?qtscience_support_page_related_con=0\#qt-science_support_page_related_con

26. Abo-Taha M., Ahmed H., El-Molla A. (2021), "Floodplain Mapping Using Integration between Hydrologic Model (GIS) and Hydrodynamic Model (HEC-RAS)", The 15th International Al-Azhar Engineering Conference 